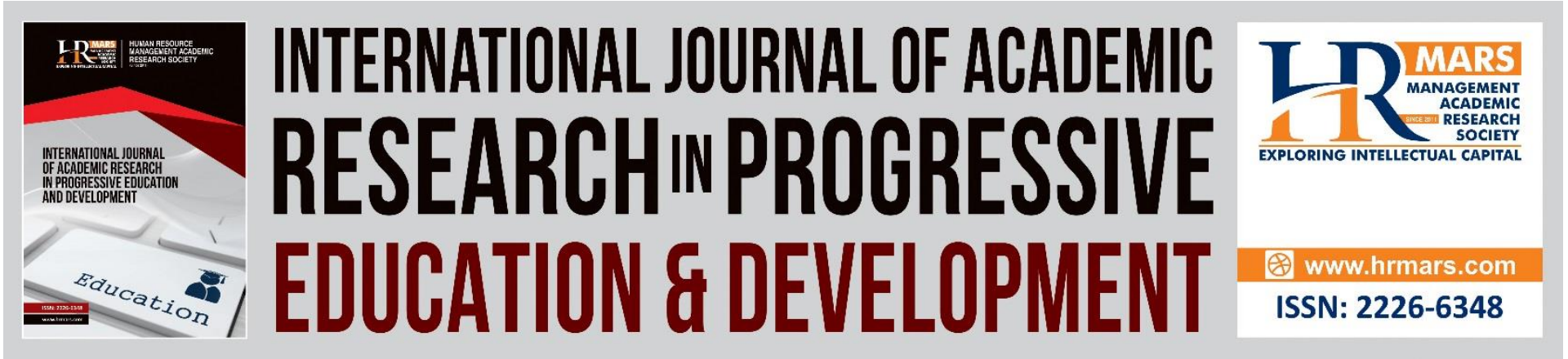

\title{
Perceived E-Learning Conditions of Malaysian Undergraduates
}

Soo Kum Yoke, Noriah Ismail

To Link this Article: http://dx.doi.org/10.6007/IJARPED/v10-i3/10858

DOI:10.6007/IJARPED/v10-i3/10858

Received: 01 June 2021, Revised: 05 July 2021, Accepted: 27 July 2021

Published Online: 22 August 2021

In-Text Citation: (Yoke \& Ismail, 2021)

To Cite this Article: Yoke, S. K., \& Ismail, N. (2021). Perceived E-Learning Conditions of Malaysian Undergraduates. International Journal of Academic Research in Progressive Education and Development, 10(3), 286-294.

Copyright: (C) 2021 The Author(s)

Published by Human Resource Management Academic Research Society (www.hrmars.com)

This article is published under the Creative Commons Attribution (CC BY 4.0) license. Anyone may reproduce, distribute, translate and create derivative works of this article (for both commercial and non-commercial purposes), subject to full attribution to the original publication and authors. The full terms of this license may be seen

at: http://creativecommons.org/licences/by/4.0/legalcode

\section{Vol. 10(3) 2021, Pg. 286 - 294}

Full Terms \& Conditions of access and use can be found at http://hrmars.com/index.php/pages/detail/publication-ethics 


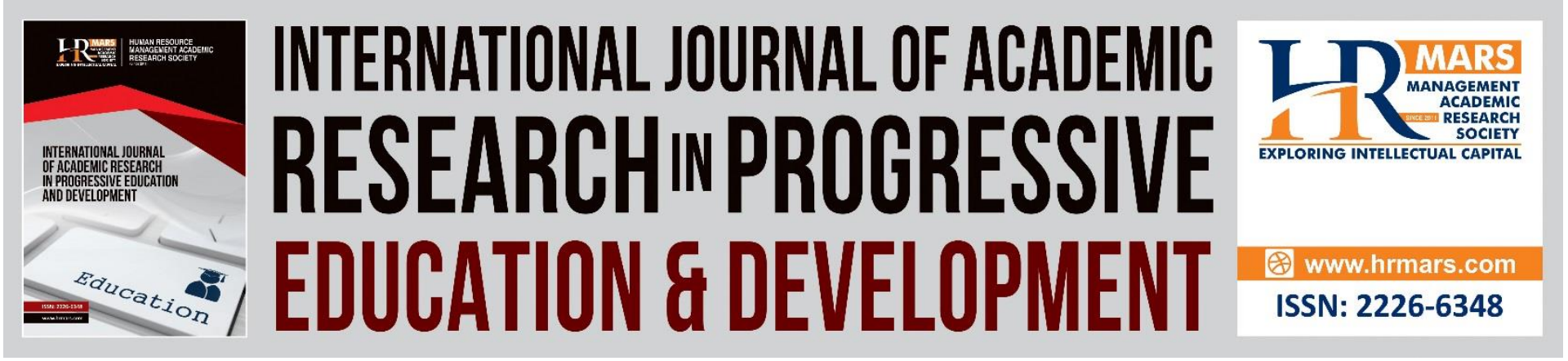

\title{
Perceived E-Learning Conditions of Malaysian Undergraduates
}

\author{
Soo Kum Yoke \\ Universiti Teknologi MARA Cawangan Negeri Sembilan, Malaysia \\ Email: sooku607@uitm.edu.my \\ Noriah Ismail \\ Universiti Teknologi MARA Cawangan Johor, Malaysia \\ Email: noriah135@uitm.edu.my
}

\begin{abstract}
Current education systems have been placed in e-learning modes as the world tackles the health dangers of Covid-19. Students have been placed at their home environments and subjected to learning via online technology to enable learning to take place even in these conditional situations. A lot of attention has been given to how students perceived their learning. To find out how students perceived their learning condition, the present study aims to investigate the perception of e-learning among Malaysian undergraduates. The objectives are mainly to identify students' perception towards being subjected to e-learning conditions and to determine students' perceptions of the advantages of having e-learning to substitute for face-to-face learning. The study used quantitative analysis based on an online survey which was disseminated to 79 respondents through social media. The results revealed that students have positive experience with e-learning and think that it should be an option provided by the university. Even though many still prefer face-to-face learning compared to e-learning, they admitted that e-learning has some advantages such as improving their skills in finding information on the internet, saving money from transportation to the university, becoming more independent and becoming more appreciative of their learning.
\end{abstract}

Keywords: E-Learning, Online Learning, Open Distance Learning, Students' Perception, Malaysian Undergraduates

\section{Introduction}

COVID-19 has resulted in the shutdown of schools all across the world. Globally, over 1.2 billion children are out of the classroom. However, as society strives to accommodate the current education crisis, educators and learners are encouraged to embrace online teaching and learning. Insofar education has changed dramatically, with the distinctive rise of elearning, whereby teaching is undertaken remotely and on digital platforms. With this sudden shift away from the classroom in many parts of the globe, some are wondering whether the adoption of online learning will continue to persist post-pandemic, and how such a shift would 
impact the worldwide education market. Moreover, there are the important issues that need to be ascertained such as those related to students' readiness towards e-learning, the benefits as well as the possible drawbacks of e-learning particularly the new hybrid model of online and distance learning which has been applied among Malaysian undergraduates.

Malaysian education system has for more than two decades strived for e-learning. Like most Asian countries, lack of internet coverage and financial funding for home based e-learning has been particularly disheartening. In lieu of such conditions, can learning persist and for how long for students to bear with their conditions are important to ensure education systems can function continuously. It is therefore highly interesting to look seriously at this matter in the viewpoint of how students perceived their learning conditions by considering the following objectives: (1) to identify students' perception towards being subjected to e-learning conditions and, (2) to determine students' perceptions of the advantages of having e-learning to substitute for face-to-face learning.

\section{Literature Review}

Students' perceptions of e-learning conditions

Due to the rapid expansion of technology in recent years as well as the present Covid-19 pandemic situation, online education or e-learning is increasing exponentially in the higher learning institutions and has precipitated changes in the modes of teaching and learning in Malaysian universities. The challenge for higher learning institutions during the Covid-19 pandemic is to provide viable and meaningful learning experience through the right e-learning courses or program which can enhance tertiary students' self-development and academic achievements.

As universities are increasingly turning to e-learning techniques and tools to deliver instruction, the challenge for the web developers, higher learning administrators and educators is to develop the right e-learning programs for students (Chung, Subramaniam \& Dass, 2020). Ideally, an effective e-learning program should provide students with a range of online tools and resources that can help to enhance their learning ability, guide them to be autonomous learners. Furthermore, an e-learning program should also provide meaningful activities and materials that can stimulate learning interest and alter the negative attitude of some students towards online learning. If such aims can be achieved then the program can be said to be successful (Ismail et al., 2015; Soo et al., 2021).

Furthermore, Mahmud et al (2018) believes that students' favorable views and conviction of e-learning effectiveness as well as their lecturer's expertise and commitment help to reinforce their positive attitude towards it and in turn motivate them to be actively engaged in the learning, which subsequently enhances their performance. Hence, students will appreciate and value the chance to learn via an effective and suitable e-learning course.

Similarly, Peng (2010) postulates that students' acceptance and attitude towards a certain e-learning course is crucial in determining the success of the course and to ensure their dedication and interest in it. A number of previous studies also indicate the importance of students' favorable views regarding e-learning programs and felt that it has changed their negative attitudes towards learning such as (Ismail, Hussin and Darus, 2016; Crawford, 2017; and Halili, 2019).

Several studies reported positive repercussions on the pedagogically more innovative and engaging e-learning compared to the traditional and passive face to face learning instruction (Ismail, Albakri, 2013; Sundgren, 2017; Chung, et al., 2020). An effective e-learning 
instruction can result in positive motivation, immediacy and interaction within the landscape of online teaching and learning. Deliberating on similar findings, it was reported that students felt more motivated and had better attitudes towards e-learning thus contributing to one of the important attributes to the success of computer-assisted environments (Stephens \& Coryell, 2020).

A study by Chung and Mathew (2020) aimed at finding out if university students' gender, study program, geographical location and internet connection have an effect on their online learning satisfaction and intention to continue using online learning in the future during the COVID-19 pandemic. Data collected from 608 students using simple random sampling from several campuses of Universiti Teknologi MARA Malaysia was analysed using frequency, cross tabulation, Chi-square test and multiple regression analysis methods. The findings revealed that six in every ten respondents are satisfied with their online learning. As for their intention to continue using online learning in the future, more male, diploma and West Malaysian students with average internet connection do not intend to do so in the future. Apart from that, online learning satisfaction is a significant predictor of students' intention to continue with online learning in the future.

While some believe that the unplanned and rapid move to online learning - with no training, insufficient bandwidth, and little preparation - will result in a poor user experience that is unconducive to sustained growth, others believe that this rapid change to e-learning via new hybrid model of education will bring significant benefits (Paulsen \& McCormick, 2020). Many researchers believe that the integration of information technology in education will be further accelerated and that online education will eventually become an integral component of school education. Educational institutions in Malaysia, particularly tertiary level, have embarked on an unprecedented journey to find a balance between the delineated MCO regulations, and the continuation of studies for their students. (Mahmud \& Bakar, 2020).

The Technology Acceptance Model (TAM)

Technology Acceptance Model or TAM was first advocated by Davis (1989) for the purpose of predicting individual users' usage of technology and their acceptance of it. The model has been widely researched on the acceptance behaviour of users towards information systems and technology (Liu, Liao \& Pratt, 2009; Ogbonnaya, 2019; Shafeek, 2011). TAM was actually derived from earlier studies in the Theory of Reasoned Action (TRA). TRA focused on individual users' acceptance behaviour towards information technology. TAM seeked to answer why an individual's attitude and belief influenced his or her acceptance or rejection of information technology. Specifically, two attitudes were considered which are (1) perceived usefulness and (2) perceived ease of use. 


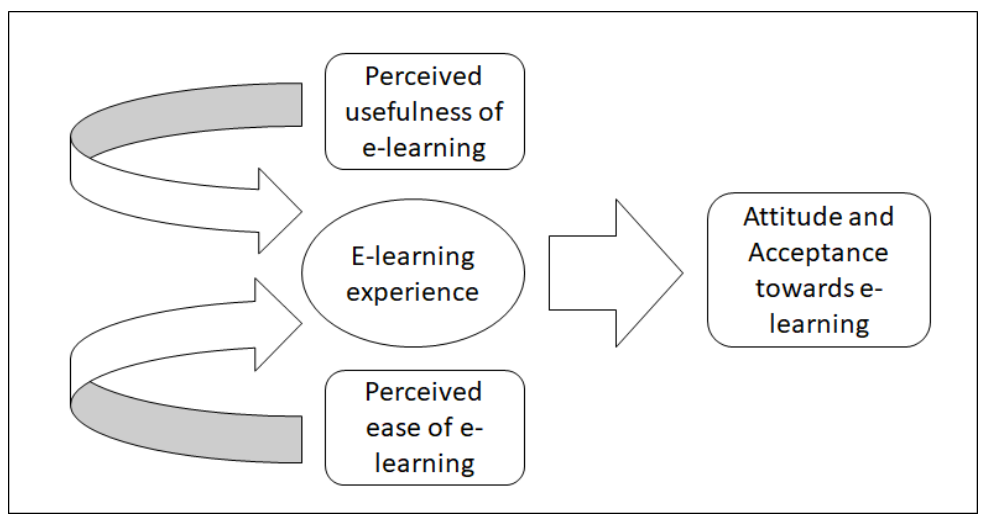

Figure 1: E-learning framework (adapted from TAM by Davis, 1989)

Figure 1 shows the e-learning framework for the study adapted from the TAM model by Davis (1989). In adapting the two attitudes brought about by TAM, the study used perceived usefulness of e-learning and perceived ease of e-learning to determine the attitude and acceptance towards e-learning as shown in the framework.

\section{Methodology}

A quantitative research was carried out to find out how students perceived e-learning especially in the current movement control condition where teachers and students are physically separated during instruction and have to use technologies to communicate and interact. The objectives were to identify students' perception towards being subjected to elearning conditions and to determine students' perceptions of advantages of e-learning.

\section{Respondents of the study}

To facilitate the study, 79 undergraduates from a local university were randomly selected. They consisted of students aged 20 years and above, who were doing their bachelor's degree at the university. They have all been subjected to at least 6 months of e-learning from their homes.

\section{Research Instrument}

The study was conducted by means of an online survey form. The online survey form was created using the google form platform. The items were partially derived from an adaptation of the TAM model (Davis, 1989) and was named the e-learning framework for the study. The questionnaire consisted of 25 items. The 25 items were divided into 3 parts. Part A focused on the respondents' demographics while Part B focused on the students' perception towards being subjected to e-learning and Part $C$ focused on the students' perceptions of advantages of e-learning.

\section{Procedure and Data Analysis}

The online survey form was disseminated to a hundred respondents who were randomly assigned. However, only 79 responses were found to be useful for the purpose of the study. The data sampling was then descriptively analysed to provide summaries and conclusions about the samples involved in the study. The results however, cannot be generalized to the whole population of undergraduates. The descriptive statistics obtained from the study were used to attain the objectives of this study. 
DEVELOPMENT

Vol. 10, No. 3, 2021, E-ISSN: 2226-6348 @ 2021 HRMARS

\section{Findings}

This section of the study discusses the findings of the study in relation to the objectives set for the study which were (1) to identify students' perception towards being subjected to elearning conditions and, (2) to determine students' perceptions of the advantages of having e-learning to substitute for face-to-face learning. The findings and results will be arranged according to the demographics of the respondents, the students' perception towards elearning and the students' perception towards the advantages of e-learning.

\section{Demographics of the respondents}

Table 1 below shows the demographics of the respondents in terms of gender, age, education level, location and computer skills.

Table 1. Demographics of the respondents

\begin{tabular}{|l|l|l|l|}
\hline Variable & Type & Frequency & Percentage \\
\hline Gender & Male & 18 & 22.78 \\
& Female & 61 & 77.22 \\
\hline Age & Under 20 years old & 0 & - \\
& 20 years old and above & 79 & 100.00 \\
\hline Education level & Diploma & 0 & - \\
& Degree & 79 & 100.00 \\
\hline Location & Urban & 37 & 46.83 \\
& Suburban & 33 & 41.77 \\
& Rural & 9 & 11.40 \\
\hline Computer Skills & Good & 26 & 32.91 \\
& Moderate & 52 & 65.82 \\
& Poor & 1 & 1.27 \\
\hline
\end{tabular}

In table 1, the findings show that 22.78 percent of the respondents were male while 77.22 percent were female. All the respondents (100 percent) were 20 years old and above. Also, all the respondents (100 percent) were at the degree level of their education. In addition, it was found that 46.83 percent of the respondents live in urban areas, 41.77 percent of the respondents live in suburban areas and 11.40 percent of the respondents live in rural areas. Furthermore, 32.91 percent of the respondents had good computer skills while 65.82 percent of the respondents had moderate computer skills and 1.27 percent of the respondents had poor computer skills. Hence, this indicates that the majority of the respondents are female, 20 years old and above, studying at the degree level, living in urban areas and have moderate computer skills.

Students' perception towards being subjected to e-learning

Since the directive to close learning institutions due to the Covid-19 pandemic, students have been left without an option but to succumb to e-learning from their homes. Table 2 shows the students' perception towards being subjected to e-learning in this condition. 
INTERNATIONAL JOURNAL OF ACADEMIC RESEARCH IN PROGRESSIVE EDUCATION AND

DEVELOPMENT

Vol. 10, No. 3, 2021, E-ISSN: 2226-6348 @ 2021 HRMARS

Table 2. Students' perception towards being subjected to e-learning

\begin{tabular}{|c|c|c|c|c|}
\hline \multirow[t]{2}{*}{ Items } & \multicolumn{3}{|c|}{ Percentage } & \multirow[t]{2}{*}{ Mode } \\
\hline & Yes & No & $\begin{array}{l}\text { Mayb } \\
\text { e }\end{array}$ & \\
\hline $\begin{array}{l}\text { 1. Have you experienced e-learning before the } \\
\text { Movement Control Order (MCO)? }\end{array}$ & 74.6 & 16.4 & 9.0 & Yes \\
\hline 2. Do you think e-learning is good? & 26.5 & 11.3 & 62.2 & $\begin{array}{l}\text { Mayb } \\
\text { e }\end{array}$ \\
\hline $\begin{array}{l}\text { 3. Do you think that e-learning should be an option for } \\
\text { students at the university? }\end{array}$ & 48.1 & 18.9 & 33.0 & Yes \\
\hline $\begin{array}{l}\text { 4. Do you think that e-learning is better than face-to- } \\
\text { face learning? }\end{array}$ & 5.0 & 67.0 & 28.0 & No \\
\hline 5. Do you think that e-learning helps you learn better? & 12.6 & 36.7 & 50.7 & $\begin{array}{l}\text { Mayb } \\
\text { e }\end{array}$ \\
\hline $\begin{array}{l}\text { 6. Do you think that e-learning is suitable to be done } \\
\text { from home? }\end{array}$ & 36.7 & 36.7 & 26.6 & $\begin{array}{l}\text { Yes/N } \\
\text { o }\end{array}$ \\
\hline $\begin{array}{l}\text { 7. Do you think that the environment at home is } \\
\text { conducive for e-learning? }\end{array}$ & 13.9 & 48.1 & 38 & No \\
\hline $\begin{array}{l}\text { 8. Do you think it is better to have face-to-face } \\
\text { communication with your lecturer? }\end{array}$ & 96.2 & 0.0 & 3.8 & Yes \\
\hline $\begin{array}{l}\text { 9. Do you think that it is hard to get information } \\
\text { without the physical library facility? }\end{array}$ & 67.0 & 20.2 & 12.8 & Yes \\
\hline $\begin{array}{l}\text { 10. Do you think it is difficult to have e-learning classes } \\
\text { because your family is not cooperative? }\end{array}$ & 48.1 & 18.9 & 33.0 & Yes \\
\hline
\end{tabular}

In table 2, the findings show that 74.6 percent of the respondents have experienced elearning before the Movement Control Order. Furthermore, 48.1 percent of the respondents think that e-learning should be an option for students at the university. Majority of the respondents ( 96.2 percent) think that it is better to have face-to-face communication with their lecturer. Besides that, they also felt that it was hard to get information without the physical library facility (67 percent). Also, they think that it is difficult to have e-learning classes because their family is not always cooperative (48.1 percent). Overall, the results revealed that the students had some experience with e-learning and felt that it was a good option to be given to the students. However, the results also revealed that the students preferred face-to-face communication rather than e-learning. They found it difficult to have e-learning classes at home as the family members may not always be cooperative.

Students' perception of the advantages of e-learning

The question of whether the e-learning experience from home benefited the students in any way was addressed and table 3 shows the students' response to their perception of the advantages of e-learning. 
INTERNATIONAL JOURNAL OF ACADEMIC RESEARCH IN PROGRESSIVE EDUCATION AND

DEVELOPMENT

Vol. 10, No. 3, 2021, E-ISSN: 2226-6348 @ 2021 HRMARS

Table 3. Students' perception of the advantages of e-learning

\begin{tabular}{|l|l|l|l|l|l|l|}
\hline \multirow{2}{*}{ Items } & \multicolumn{1}{l|}{ Percentage } & Mode \\
\cline { 2 - 6 } & $\mathbf{1}$ & $\mathbf{2}$ & $\mathbf{3}$ & $\mathbf{4}$ & $\mathbf{5}$ & \\
\hline $\begin{array}{l}\text { 1. E-learning enables me to learn from home } \\
\text { or anywhere I want. }\end{array}$ & 2.53 & 5.06 & 36.70 & 31.60 & 24.05 & 3 \\
\hline $\begin{array}{l}\text { 2. E-learning helps me to better my skills at } \\
\text { finding information from the internet }\end{array}$ & 1.26 & 1.26 & 31.60 & 37.97 & 27.84 & 4 \\
\hline $\begin{array}{l}\text { 3. I am able to connect any time and any place } \\
\text { with my lecturers and classmates via e- }\end{array}$ & 1.26 & 12.65 & 44.30 & 27.84 & 13.92 & 3 \\
learning. & & & & & \\
\hline $\begin{array}{l}\text { 4. E-learning helps me save money for } \\
\text { transportation as I don't have to pay to travel } \\
\text { to the university. }\end{array}$ & 0.00 & 0.00 & 16.45 & 35.44 & 48.10 & 5 \\
\hline $\begin{array}{l}\text { 5. E-learning helps me to be more disciplined } \\
\text { when it comes to my studies and assignments. }\end{array}$ & 10.12 & 15.18 & 44.30 & 22.78 & 7.59 & 3 \\
\hline $\begin{array}{l}\text { 6. E-learning helps me to be more } \\
\text { independent in my learning as I have to find } \\
\text { information for myself. }\end{array}$ & 2.53 & 2.53 & 29.11 & 44.30 & 21.51 & 4 \\
\hline $\begin{array}{l}\text { 7. E-learning helps me to be more } \\
\text { appreciative of my studies compared to when } \\
\text { I have to go to college to learn. }\end{array}$ & 3.79 & 7.59 & 35.44 & 37.97 & 15.18 & 4 \\
\hline $\begin{array}{l}\text { 8. E-learning makes me more conscious of my } \\
\text { studies as I have to schedule myself to be in } \\
\text { front of the computer to learn. }\end{array}$ & 2.53 & 8.86 & 41.77 & 36.70 & 10.12 & 3 \\
\hline $\begin{array}{l}\text { 9. E-learning helps me to give more attention } \\
\text { to my lessons. }\end{array}$ & 11.39 & 26.58 & 39.24 & 15.18 & 7.59 & 3 \\
\hline $\begin{array}{l}\text { 10. E-learning helps me to be more focused in } \\
\text { class. }\end{array}$ & 27.84 & 24.05 & 37.97 & 16.45 & 7.59 & 3 \\
\hline
\end{tabular}

In table 3, the findings show that the students strongly agree that e-learning helps them save money for transportation as they don't have to pay to travel to the university (48.10 percent). They also agreed that e-learning helps them to better their skills at finding information from the internet ( 37.97 percent). They further agreed that e-learning helps them to be more independent in their learning as they have to find information for themselves (44.30 percent). In addition, they agreed that e-learning helps them to be more appreciative of their studies compared to when they have to go to college to learn (37.97 percent). Thus, the results revealed that the students did benefit from the e-learning situation and some of the advantages include saving money on transportation, independent learning, and becoming more appreciative of their studies.

\section{Conclusion}

It is noteworthy to mention that e-learning provides significant benefits to university students particularly during this Covid-19 pandemic whereby the shift to hybrid online learning is inevitable. This is evident in the main findings whereby; the students claimed to have positive experience with e-learning and think that it should be an option provided by the university. However, it is interesting to note that many would still prefer blended learning and face-to- 
face learning compared to total e-learning. The findings also showed the students' skills in finding information on the internet, saving money from transportation to the university, becoming more autonomous in learning as well as more appreciative of their learning. For future research, it is recommended that researchers utilize various techniques when collecting data such as gathering qualitative data from interviews. Lastly, future research can also include a larger sample size so that the findings can be generalized and applied to a larger representation of populations.

\section{References}

Chung, E., \& Mathew, V. N. (2020). Satisfied with Online Learning Amidst COVID-19, but do you Intend to Continue Using it? International Journal of Academic Research in Progressive Education and Development, 9(4), 67-77.

Chung, E., Subramaniam, G., \& Dass, L. C. (2020). Online Learning Readiness among University Students in Malaysia amidst COVID-19. Asian Journal of University Education, 16(2), 4658. Crawford, R. (2017). Rethinking teaching and learning pedagogy for education in the twenty-first century: blended learning in music education. Music Education Research, 19(2), 195-213

Davis, F. D. (1989), "Perceived usefulness, perceived ease of use, and user acceptance of information technology", MIS Quarterly, 13 (3): 319-340, doi:10.2307/249008

Halili, S. H. (2019). Technological advancements in education 4.0. The Online Journal of Distance Education and E-Learning, 7(1), 63-69.

Liu, S. H., Liao, H. L., \& Pratt, J. A. (2009). Impact of media richness and flow on e-learning technology acceptance. Computers \& Education, 52(3), 599-607.

Mahmud, M. M., \& Bakar, M. S. A. (2020). E-Learn: An Online Platform for Teaching and Learning. International Journal of Academic Research in Progressive Education and Development, 9(4), 78-92.

Ogbonnaya, U. I. (2019). Adoption and Perceived Usefulness of Social Media by Pre-service Teachers in Nigeria. International Journal of Interactive Mobile Technologies, Vol.13 (6).

Paulsen, J., \& McCormick, A. C. (2020). Reassessing disparities in online learner student engagement in higher education. Educational Researcher, 49(1), 20-29.

Peng, S. C. (2010). "The Implementation of Online Learning for ESL Programs: Factors and Perspectives." An unpublished PhD dissertation. Faculty of USC Rossier School of Education, University of Southern California.

Shafeek, S. A. (2011). E-learning technology acceptance model with cultural factors. MSc. Thesis, Liverpool John Moores University, School of Computing and Mathematical Sciences.

Soo, K. Y., Hasan, N. H., Ahmad, S. T. S. A., Ismail, N., Zainon, S., \& Abdullah, M. (2021). Exploring the Design of Online Content for e-learning. e-Proceedings of International Conference on Language, Education, Humanities \& Social Sciences ( $i$ LEdHS2021),pp.421-429.

Stephens, M. L., \& Coryell, J. (2020). Faculty Perspectives on Context, Benefits, and Challenges in Fully Online Graduate Adult Education Programs. Adult Learning, 1045159520959468.

Sundgren, M. (2017). Blurring time and place in higher education with bring your own device applications: a literature review. Education and Information Technologies, 22(6), 30813119 